\title{
Quantification and Inheritance of Antioxidant Properties and Mineral Content in Ridge Gourd (Luffa acutangula)
}

\author{
Pradip Karmakar • A. D. Munshi • T. K. Behera $\cdot$ Ravinder Kumar • \\ A. K. Sureja $\cdot$ C. Kaur $\cdot$ B. K. Singh
}

Received: 28 December 2012/ Accepted: 5 June 2013/Published online: 25 July 2013

(C) NAAS (National Academy of Agricultural Sciences) 2013

\begin{abstract}
With a view to develop nutritious ridge gourd variety, a field as well as a laboratory study was conducted to quantify and enumerate the genetic control for antioxidant properties and mineral content in fruits. The hybrids were found to be superior over their parents for various nutritional traits such as ascorbic acid, total carotenoids and total phenolics content; in vitro antioxidant activity in the form of DPPH-RSA, ABTS-RSA and CUPRAC; and P, K, Ca, Na, S, Fe, Zn and $\mathrm{Mn}$ content in the fruits. All the nutritional parameters exhibited higher values of dominance variance over the additive genetic variance, more than unity value of average degree of dominance and low narrow-sense heritability $(<50 \%)$. The antioxidants and mineral content in the fresh fruits are predominantly attributed by the non-additive genetic component. Hence, the various tools of hybrid breeding would be useful to breed antioxidants- and minerals-rich genotypes of ridge gourd (Luffa acutangula Roxb.).
\end{abstract}

Keywords Antioxidants - Minerals · Inheritance $\cdot$ Dominance effect $\cdot$ Additive effect ·

Ridge gourd (Luffa acutangula Roxb.)

\section{Introduction}

Ridge gourd (Luffa acutangula Roxb.) is a cucurbitaceous summer vegetable of South-east Asia and few African countries. It is also known as ribbed gourd, angled loofah and Chinese okra. The young tender fruits of the non-bitter types are eaten fresh like cucumbers, cooked as a vegetable or used in the soups. Antioxidants and minerals are integral part of human and plant nutrition to support the various biological processes during various stages of growth and

\footnotetext{
A. D. Munshi - T. K. Behera - R. Kumar - A. K. Sureja Division of Vegetable Science, IARI, Pusa, New Delhi 110012, India

P. Karmakar $(\bowtie) \cdot$ B. K. Singh

IIVR, Shahanshahpur, Varanasi 221305, Uttar Pradesh, India

e-mail:pradip9433@gmail.com

C. Kaur

Division of Post Harvest Technology, IARI, Pusa,

New Delhi 110012, India
}

developments. An appropriate plant-based diet can supply sufficient amount of nutrition to satisfy human dietary requirements. The chemical constituents of ridge gourd fruits include carbohydrates, carotene, fat, protein, phytin, flavonoids, saponin and amino acids. Kandlakunta et al. [15] reported that ribbed gourd contains about $300 \mu \mathrm{g} \beta$-carotene and $1,000 \mu \mathrm{g}$ carotenoids per $100 \mathrm{~g}$ of fresh fruits. It has various pharmacological activities like hepatoprotective, antidiabetic, antioxidant, abortifacient and antifungal activity [10]. The ribosome-inactivating proteins (RIPs), luffins, have been isolated from Luffa and characterized [16]. A purified protein with molecular weight of $30 \mathrm{kD}$ from seeds of $L$. aegyptiaca inhibited cell-free translation [24]. A recent report shows that the water extracts from fresh sponge gourds exhibited scavenging effect in terms of 1,1-diphenyl-2-picrylhydrazyl radical scavenging activity (DPPH-RSA) and butylated hydroxyanisole scavenging effect [5]. The fresh fruits of L. acutangula exhibited antioxidant activity [2]. Other than DPPH-RSA, in vitro antioxidant activity is also measured in terms of 2,2-azinobis-(3ethylbenzthiazoline-6-sulphonic acid) radical scavenging 
activity (ABTS-RSA) and cupric ion reducing antioxidant capacity assay (CUPRAC assay).

Minerals including both macro- and micronutrients such as nitrogen $(\mathrm{N})$, phosphorus $(\mathrm{P})$, potassium $(\mathrm{K})$, calcium $(\mathrm{Ca})$, magnesium $(\mathrm{Mg})$, sulphur $(\mathrm{S})$, sodium $(\mathrm{Na})$, iron $(\mathrm{Fe})$, zinc $(\mathrm{Zn})$, manganese $(\mathrm{Mn})$, copper $(\mathrm{Cu})$, cobalt $(\mathrm{Co})$, boron (B) and molybdenum (Mo) are required by living organisms to support the various biological processes during different stages of life cycle. Billions of people in developing countries suffer from micronutrient malnutrition 'hidden hunger'. The fruits of ridge gourd contain fair amount of minerals and fibre [14]. Tough sufficient amount of information related to inheritance of horticultural traits in ridge gourd had been reported by various researchers $[17,26]$, however, till now only limited information is available on the estimate of genetic component of variation for mineral content and antioxidant activity in this crop.

Being a one of the commonly used cucurbitaceous vegetables, it is essential to study the nutritional properties and the transmissibility to its progenies for identifying and developing superior genotypes. A detailed knowledge about the magnitude and nature of genetic variation in a specific population is of prime importance for the effective prediction of the suitable breeding programmes. The numerical analysis of diallel provides detailed account of additive and dominance components and the allied statistics. Till date only sparse information is available on nutritional contents and their inheritance in various vegetable crops, and none of the studies describe the gene action for antioxidants (ascorbic acid, total carotenoids, total phenolics, DPPH-RSA, ABTS-RSA and CUPRAC assay) and minerals ( $\mathrm{P}, \mathrm{Ca}, \mathrm{K}, \mathrm{Na}, \mathrm{S}, \mathrm{Fe}, \mathrm{Zn}$ and $\mathrm{Mn}$ ) in ridge gourd. Hence, the objectives of this experiment were to quantify antioxidant properties and mineral content, to enumerate the magnitude and nature of gene action, and also to suggest suitable breeding approaches for improving the nutritional quality of ridge gourd (L. acutangula) fruits.

\section{Materials and Methods}

Experimental Material, Field Experiment and Sampling

The seeds of seven parents, and $21 \mathrm{~F}_{1}$ hybrids developed through half diallel fashion were sown during rainy season of 2008-2009 at Vegetable Research Farm, IARI, New Delhi, India. The experiment was laid out in RBD with three replications. Crops were raised as per the recommended package of practices followed for ridge gourd cultivation to have better phenotypic and morphological expression. The experimental plot was fed with FYM @ 20 $\mathrm{t} \mathrm{ha}{ }^{-1}, \mathrm{~N} @ 70 \mathrm{~kg} \mathrm{ha}^{-1}$, and P and K@25 kg ha ${ }^{-1}$. At edible fruit maturity, three fruits were harvested randomly from all 28 genotypes in each replication.

\section{Determination of Antioxidant Properties}

The collected fruit samples were chopped to homogenize and $5 \mathrm{~g}$ of it was taken as sample for estimation. The amount of ascorbic acid (mg $100 \mathrm{~g}^{-1}$ fresh weight), total carotenoid (mg $100 \mathrm{~g}^{-1}$ fresh weight) and total phenolics (gallic acid equivalent $\mathrm{mg} 100 \mathrm{~g}^{-1}$ fresh weight) content were determined as described by Albrecht [1], Ranganna [25] and Singleton et al. [33], correspondingly. Moreover, the in vitro antioxidant activity (TEAC $\mu$ mol Trolox $100 \mathrm{~g}^{-1}$ ) such as DPPH-RSA, ABTS-RSA and CUPRAC assay was measured according to the respective methods of Brand-Williams et al. [6], Re et al. [27] and Apak et al. [3].

\section{Determination of Mineral Content}

The sampled fruits were chopped and $100 \mathrm{~g}$ of fresh material was kept in hot air oven at $60-65^{\circ} \mathrm{C}$ for drying. The dried samples were grounded, passed through $1 \mathrm{~mm}$ sieve and finally stored in airtight container until the digestion [30]. An amount of $0.5 \mathrm{mg}$ dried tissues were pre-digested with $15 \mathrm{ml}$ diacid mixture of perchloric acid and nitric acid in a ratio of $1: 1$ (w/w) overnight and then heated up to $250{ }^{\circ} \mathrm{C}$ until the solution turned colourless. The filtrate was used for determining concentration of $\mathrm{Zn}$, Fe and Mn on AAS (AAS-4141). Furthermore, K, Na and $\mathrm{Ca}$ concentrations were measured in the filtrate using Flame Photometer (ELICO CL-361); while, P and S content were measured through Spectrometer. The content of $\mathrm{P}, \mathrm{Ca}, \mathrm{K}$ and $\mathrm{Na}$ was expressed as $\mathrm{mg} 100 \mathrm{~g}^{-1}$; while $\mathrm{S}, \mathrm{Fe}$, $\mathrm{Zn}$ and Mn content was calculated in $\mu \mathrm{g} 100 \mathrm{~g}^{-1}$ on fresh weight basis.

\section{Statistical Analysis}

Data regarding content and in vitro activity of antioxidants, and mineral content in ridge gourd fruit were statistically analysed to study gene action using diallel method of numerical approach given by Hayman [12] through Statistical Package for Agricultural Research 2.0 (SPAR 2.0) software of Indian Agricultural Statistical Research Institute (IASRI), New Delhi, India.

\section{Results and Discussion}

Antioxidant Properties of Parents and Hybrids

The fresh fruits of ridge gourd were analysed for antioxidant properties viz., ascorbic acid, total carotenoids, total 
phenolics content and in vitro antioxidant activity in terms of DPPH-RSA, ABTS-RSA and CUPRAC assay in seven parents and their 21 half diallel derived $\mathrm{F}_{1}$ hybrids (Figs. 1, 2 ). The values of ascorbic acid, total carotenoids, total phenolics content, DPPH-RSA, ABTS-RSA and CUPRAC assay varied significantly in varieties used as parental lines and hybrids which were higher about 1.63-fold, 1.83-fold and 2.01-fold, 1.38-fold, 1.37-fold and 1.39-fold, respectively, in hybrids over their parents. The average value of $21 \mathrm{~F} 1$ hybrids for ascorbic acid, total carotenoids and total phenolics content and in vitro antioxidant activity in terms of DPPH-RSA, ABTS-RSA and CUPRAC assay was higher than the average value of the seven parents. Nevertheless, the hybrids were superior over the parents with respect to antioxidant properties. This might be due to increased concentration of favourable allele in heterozygous locus in the hybrid progenies, showing heterosis for these traits, which agrees with the findings from luffa [36], tomato [35], safflower [9] and cabbage [29].

\section{Genetic Component for Antioxidant Properties}

Results pertaining to ascorbic acid, total phenolics, total carotenoids content, DPPH-RSA, ABTS-RSA and CUPRAC assay revealed that the estimates of $D, H_{1}, H_{2}$ and $h^{2}$ were highly significant (Table 1 ). The value of $H_{1}$ was greater than $D$ for all the traits related to antioxidant properties, suggesting the presence of dominant alleles in parents. The environmental influence (E) on the inheritance of these traits was negligible and non-significant. The negative values of $F$ indicated more prevalence of recessive alleles for these traits in parents. The mean degree of dominance $\left(H_{1} / D\right)^{1 / 2}$ being $1.7,2.04,2.37,1.49,1.5$ and 1.7 for ascorbic acid, total phenolics, total carotenoids, DPPHRSA, ABTS-RSA and CUPRAC assay, respectively. The mean degree of dominance greater than one for these traits

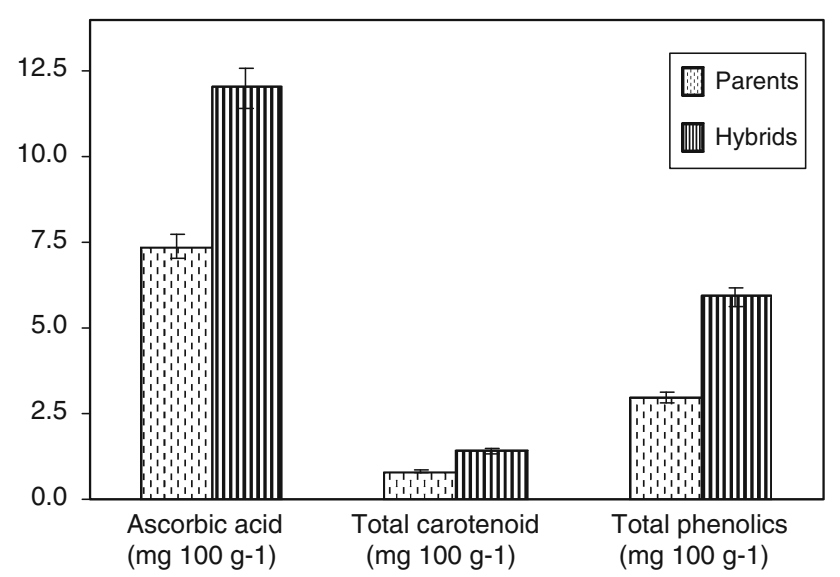

Fig. 1 Antioxidant content in parents and hybrids of ridge gourd. Standard error bars with $p<0.05$

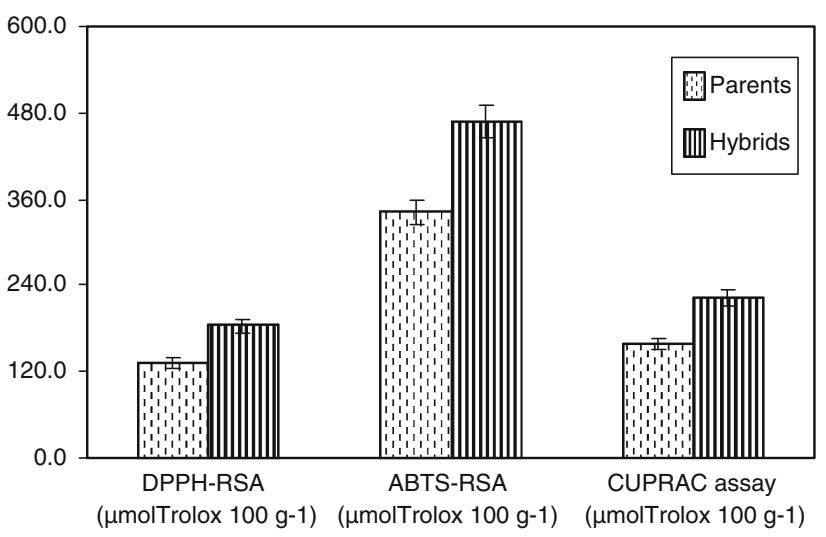

Fig. 2 Antioxidant activity in parents and hybrids of ridge gourd. Standard error bars with $p<0.05$

related to oxidative defence mechanism indicated the role of over-dominance for these characters. The proportion of genes with positive and negative effects $\mathrm{H}_{2} / 4 \mathrm{H}_{1}$ in the parents was found to be less than $0.25(0.17,0.15,0.17$, $0.18,0.19$ and 0.18 , respectively, for ascorbic acid, total phenolics, total carotenoids DPPH-RSA, ABTS-RSA and CUPRAC assay), denoting asymmetry at the loci showing dominance. The proportion of dominant and recessive gene in the parents as indicated by $\left[\left(4 D H_{1}\right)^{1 / 2}+F /\left(4 D H_{1}\right)^{1 / 2}-F\right]$ was $0.27,18.25,3.74,0.30,0.35$ and 0.32 while the group of genes, which controlled the characters and exhibited dominance $\left(h^{2} / H_{2}\right)$ was $2.33,1.43,2.95,2.19,2.85$ and 3.22 for ascorbic acid, total phenolics and total carotenoids, DPPH-RSA, ABTS-RSA and CUPRAC assay, respectively. Narrow-sense heritability being 17.15, 12.87, 10.67, 20.88, 21.39 and $17.79 \%$ for ascorbic acid, total phenolics, total carotenoids, DPPH-RSA, ABTS-RSA and CUPRAC assay, respectively, indicate that non-additive gene action has major role in the inheritance of antioxidant properties in ridge gourd fruits. The presence of more dominant genes than additive ones, minimal influence of environmental factors, preponderance of recessive alleles in parents, greater than unity value of average degree of dominance, asymmetry at loci showing dominance and low narrowsense heritability indicate that the non-additive type of gene action played an major role in the inheritance of these traits. The present investigation, therefore, indicates that the predominance of non-additive gene action for antioxidants properties implies the importance of hybrid breeding approaches to realize the higher genetic gain. The presence of dominant component for vitamin $\mathrm{C}$ content reported in towel gourd and crossbreeding may have increased its content in the fruits of this gourd [36]. In contrast, Bo et al. [4], and Navazio and Simon [19] reported recessive inheritance for $\beta$-carotene content in cucumber. Additive, dominance, additive $\times$ dominance and dominance $\times$ dominance interaction were reported for 


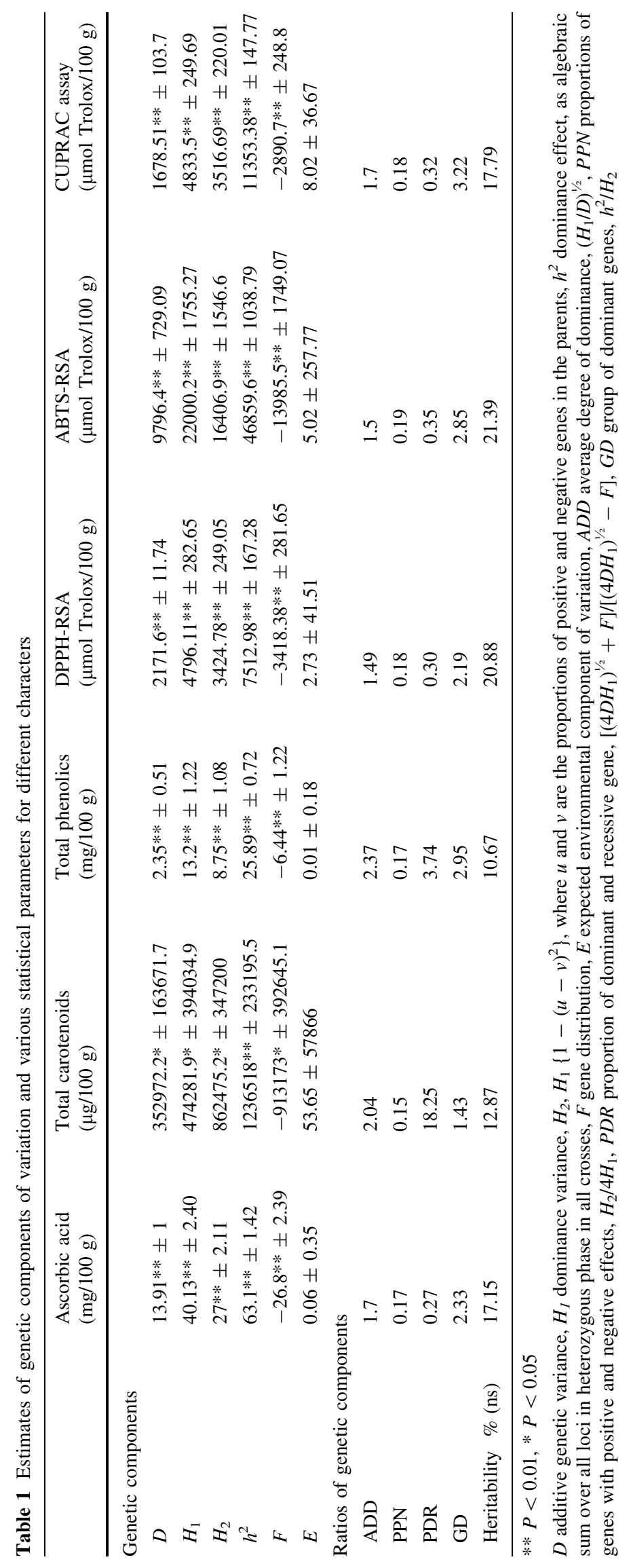




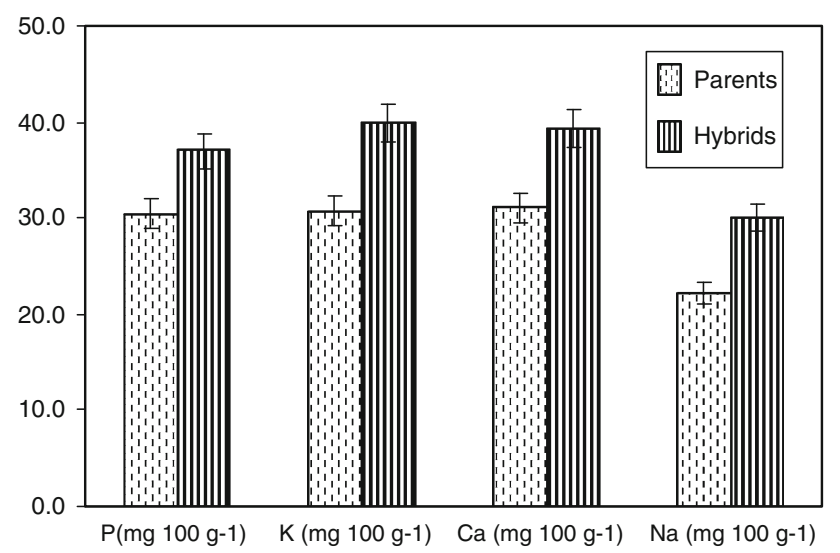

Fig. $3 \mathrm{P}, \mathrm{K}, \mathrm{Ca}$ and $\mathrm{Na}$ content in parents and hybrids of ridge gourd. Standard error bars with $p<0.05$

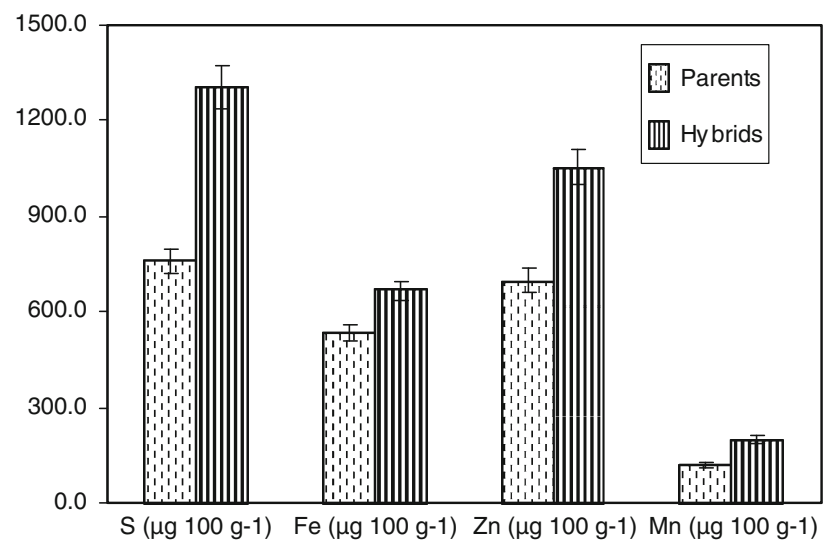

Fig. $4 \mathrm{~S}, \mathrm{Fe}, \mathrm{Zn}$ and $\mathrm{Mn}$ content in parents and hybrids of ridge gourd. Standard error bars with $p<0.05$

carotenoid content in carrot [28]. The genetic analysis showed significance of the presence of additive, dominance and epistatic genes for both phenolics and antioxidant activity in cowpea [20]. Breeding for high antioxidant activity in cowpea is possible by using highly pigmented parental lines as there is positive correlation between pigmentation and antioxidant activity [21].

\section{Mineral Content of Parents and Hybrids}

The minerals content such as $\mathrm{P}, \mathrm{K}, \mathrm{Ca}, \mathrm{Na}, \mathrm{S}, \mathrm{Fe}, \mathrm{Zn}$ and Mn were estimated in fresh fruits of seven parental lines and $21 \mathrm{~F}_{1}$ hybrids (Figs. 3 and 4) and the magnitude of mineral content was significantly higher in $\mathrm{F}_{1}$ hybrids than the parents. The average content of $21 \mathrm{~F}_{1}$ hybrids for $\mathrm{P}, \mathrm{K}$, $\mathrm{Ca}, \mathrm{Na}, \mathrm{S}, \mathrm{Fe}, \mathrm{Zn}$ and $\mathrm{Mn}$ was greater as compared to the parental average, and the respective amount was calculated to be $21.7,29.9,25.9,36.0,71.1,24.6,50.7$ and $67.9 \%$ additionally. Therefore, higher value of hybrid average indicates the heterotic effect for mineral content in ridge gourd fruit. Raigon et al. [23] reported higher $\mathrm{Fe}$ and $\mathrm{Zn}$ content in $F_{1}$ hybrids of brinjal over the parental mean. In rice, $F_{1}$ hybrids had increased content of grain $\mathrm{Fe}$ and $\mathrm{Zn}$ over standard variety [18]. In contrast, reduced content of mineral nutrients was reported in the $\mathrm{F}_{1}$ hybrids as compared to the parental value in cabbage [31] and maize [7].

\section{Genetic Component for Mineral Content}

The $D, H_{1}, H_{2}$ and $h^{2}$ estimates for all the mineral content except $\mathrm{S}$ content in fruit were highly significant (Table 2). The values of $H_{1}$ were more than $D$, which signifies that dominant genes were more than additive genes for $\mathrm{P}, \mathrm{Ca}$, $\mathrm{K}, \mathrm{Na}, \mathrm{S}, \mathrm{Fe}, \mathrm{Zn}$ and $\mathrm{Mn}$ content. The environmental influence (E) on the inheritance of these traits was negligible and non-significant. The negative values of $F$ for these traits showed that recessive alleles were more frequent. The mean degree of dominance $\left(H_{1} / D\right)^{1 / 2}$ was 1.41 , $1.38,1.4,1.85,3.16,1.47,1.82$ and 1.46 for $\mathrm{P}, \mathrm{Ca}, \mathrm{K}, \mathrm{Na}$, $\mathrm{S}, \mathrm{Fe}, \mathrm{Zn}$ and $\mathrm{Mn}$, respectively. The mean degree of dominance greater than one for these mineral nutrients indicated the role of over-dominance for these traits. The proportions of genes with positive and negative effects $\left(\mathrm{H}_{2} / 4 \mathrm{H}_{1}\right)$ were $0.18,0.19,0.17,0.22,0.16,0.18,0.17$ and 0.18 , respectively, for $\mathrm{P}, \mathrm{Ca}, \mathrm{K}, \mathrm{Na}, \mathrm{S}, \mathrm{Fe}, \mathrm{Zn}$ and $\mathrm{Mn}$. These values were less than 0.25 , which implies asymmetry at the loci showing dominance. The proportion of dominant and recessive gene in the parents as indicated by $\left[\left(4 D H_{1}\right)^{1 / 2}+F /\left(4 D H_{1}\right)^{1 / 2}-F\right]$ was $0.30,0.35,0.27,0.53$, $0.26,0.27,0.29$ and 0.32 while the group of genes, which controlled the characters and exhibited dominance $\left(h^{2} / H_{2}\right)$ were 2.26, 2.16, 2.27, 1.11, 2.06, 2.06, 2.91 and 3.35 for $P$, $\mathrm{Ca}, \mathrm{K}, \mathrm{Na}, \mathrm{S}, \mathrm{Fe}, \mathrm{Zn}$ and $\mathrm{Mn}$, respectively. Narrow-sense heritability being $22.18 \%(\mathrm{P}), 22.58 \%(\mathrm{Ca}), 21.94 \%(\mathrm{~K})$, $17.88 \%(\mathrm{Na}), 6.8 \%(\mathrm{~S}), 19.96 \%(\mathrm{Fe}), 15.3 \%(\mathrm{Zn})$ and $21.48 \%(\mathrm{Mn})$ for the macronutrients and micronutrients indicated that the non-additive type of gene action played an important role in the inheritance of these mineralogical traits. Highly significant $D, H_{1}, H_{2}$ and $h^{2}$ estimate, nonsignificant value of $E$, higher magnitude $H_{1}$ over corresponding value of $D$, negative value of $F$, greater than unity value of $\left(H_{1} / D\right)^{1 / 2},<0.25$ value for $\left(H_{2} / 4 H_{1}\right)$, and lower narrow-sense heritability $(<50.0 \%)$ for $\mathrm{P}, \mathrm{Ca}, \mathrm{K}, \mathrm{Na}, \mathrm{S}$, $\mathrm{Fe}, \mathrm{Zn}$ and $\mathrm{Mn}$ point towards the non-additive type of gene action in the inheritance of these nutritional traits. Overdominance, lesser influence of environment on accumulation of minerals, the presence of more dominant genes than additive genes, preponderance of recessive alleles for these traits in parents and asymmetry at dominant loci played major role in the genetic control of mineral content in ridge gourd fruit. Hedau [13] also explored non-additive gene action to improve $\mathrm{Ca}$ and $\mathrm{P}$ content in ridge gourd fruits. Sit and Sirohi [34] reported over-dominance for $\mathrm{P}, \mathrm{Ca}, \mathrm{Fe}$ and vitamin $\mathrm{C}$ content in fruits of bottle gourd. Additive as 


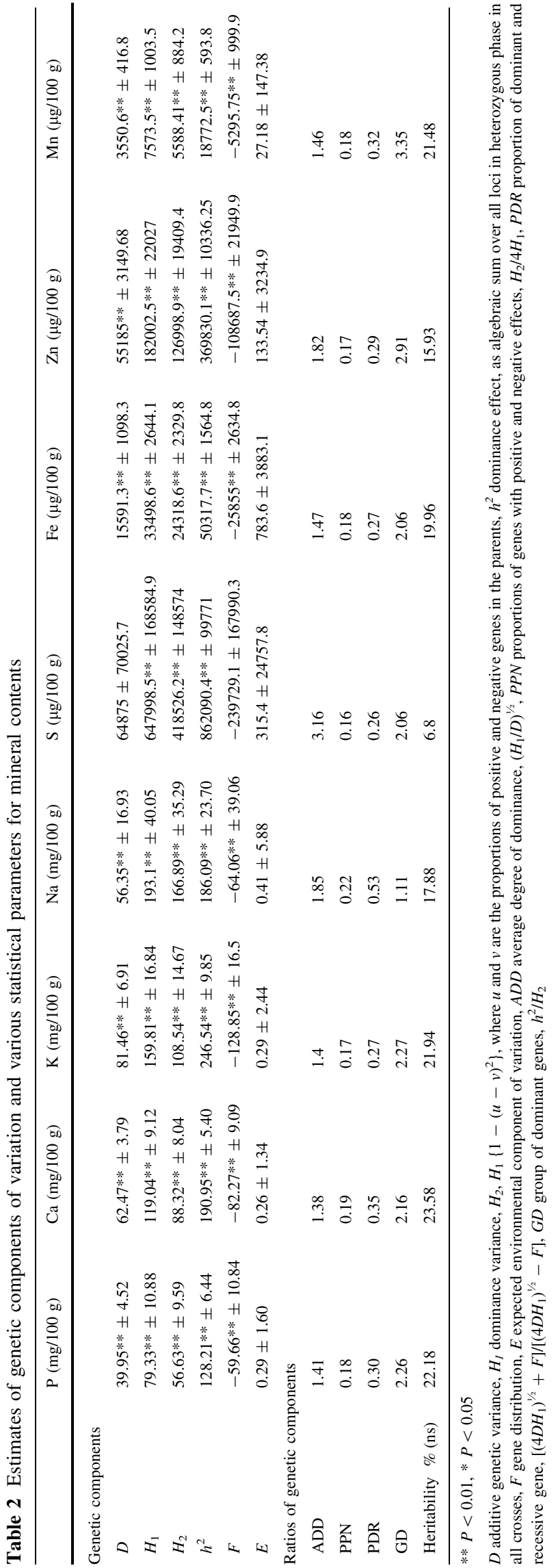

well as non-additive gene effects had been reported for the inheritance of $\mathrm{K}$ and protein content in pea [11]. Single dominant gene controls the high seed $\mathrm{Zn}$ concentration in French/navy bean [8]. Low level of narrow-sense heritability and partial dominance reported for $\mathrm{K}$ content in common bean seed [22]. Prevalence of non-additive variance and non-additive gene action for $\mathrm{Fe}, \mathrm{Zn}, \mathrm{Mn}, \mathrm{K}$ and $\mathrm{Ca}$ accumulation in cabbage was reported by Singh et al. [32].

\section{Conclusions}

In conclusion, the hybrids were superior for nutritional quality over their parents. Thus $\mathrm{F}_{1}$ hybrids provide greater opportunity for enhanced nutritional quality of ridge gourd fruits over open-pollinated varieties. Furthermore, the nutrient concentration of fruits was predominantly contributed by the non-additive genetic component; therefore, hybrid breeding approaches (heterosis, and crossbreeding and early generation selection) might be useful to improve antioxidant properties and mineral content in ridge gourd (L. acutangula Roxb.).

\section{References}

1. Albrecht JA (1993) Ascorbic acid retention in lettuce. J Food Saf 16:311-316

2. Ansari NM, Houlihan L, Hussain B, Pieroni A (2005) Antioxidant activity of five vegetables traditionally consumed by SouthAsian migrants in Bradford, Yorkshire, UK. Phytother Res 19: 907-911

3. Apak R, Guclu K, Ozyurek M, Celik SE (2008) Mechanism of antioxidant capacity assays and the CUPRAC (cupric ion reducing antioxidant capacity) assay. Microchim Acta 160:413-419

4. Bo K, Song H, Shen J, Qian C, Staub JE, Simon PW, Lou Q, Chen J (2011) Inheritance and mapping of the ore gene controlling the quantity of b-carotene in cucumber (Cucumis sativus L.) endocarp. Mol Breed 30(1):335-344

5. Bor JY, Chen HY, Yen GC (2006) Evaluation of antioxidant activity and inhibitory effect on nitric oxide production of some common vegetables. J Agric Food Chem 54:1680-1686

6. Brand-Williams W, Cuvelier ME, Berset C (1995) Use of free radical method to evaluate antioxidant activity. Food Sci Technol 28:25-30

7. Chen F, Chun L, Song J, Mi G (2007) Heterosis and genetic analysis of iron concentration in grains and leaves of maize. Plant Breed 126(1):07-109

8. Cichy KA, Forster S, Grafton KF, Hosfield GL (2005) Inheritance of seed zinc accumulation in Navy Bean. Crop Sci 45:864-870

9. Golkar P, Arzani A, Rezaei AM, Yarali Z, Yousefi M (2009) Genetic variation of leaf antioxidants and chlorophyll content in safflower. Afr J Agric Res 4(12):1475-1482

10. Gowtham KNP, Kuppast IJ, Mankani KL (2012) A review on Luffa acutangula. Int J Pharm World Res 3(1):1-15

11. Gupta KR, Waldia RS, Dahiya BS, Singh KP, Sood DR (1984) Inheritance of seed yield and quality traits in peas (Pisum sativum L.). Theor Appl Genet 69(2):133-137 
12. Hayman BI (1954) The theory and analysis of diallel crosses. Genetics 39:789-809

13. Hedau NK (2002) Study on heterosis in ridge gourd (Luffa acutangula Roxb.). Ph.D. thesis, Division of Vegetable Science, IARI, New Delhi, India

14. Hussain J, Rehman N, Khan AL, Hamayun M, Hussain SM, Shinwari ZK (2010) Proximate and essential nutrients evaluation of selected vegetables species from Kohat region, Pakistan. Pak J Bot 42(4):2847-2855

15. Kandlakunta B, Rajendran A, Thingnganing L (2008) Carotene content of some common (cereals, pulses, vegetables, spices and condiments) and unconventional sources of plant origin. Food Chem 106:85-89

16. Kishida K, Masuho Y, Hara T (1983) Protein-synthesis inhibitory protein from seeds of Lufa cylindrica L. Roem. FEBS Lett 153:209-212

17. Luo JN, Luo SB, Gong H (2000) Breeding of new $F_{1}$ hybrid 'Yalu No.1' of Luffa acutangula Roxb. China Veg 3:26-28

18. Nagesh P, Babu VR, Usharani G, Reddy TD (2012) Heterosis studies for grain iron and zinc content in rice (Oryza sativa L.). Ann Biol Res 3(1):179-184

19. Navazio JP, Simon PW (2001) Diallel analysis of high carotenoid content in cucumbers. J Am Soc Hortic Sci 126:100-104

20. Noubissie JT, Youmbi E, Njintang NY, Abatchoua MA, Nguimbou RM, Bell JM (2012) Inheritance of phenolic contents and antioxidant capacity of dehulled seeds in cowpea (Vigna unguiculata L. Walp.). Int J Agron Agric Res 2(3):7-18

21. Nzaramba MN, Hale AL, Schewing DC, Miller JC (2005) Inheritance of antioxidant activity and its association with seed coat colour in cowpea. J Am Soc Hortic Sci 130(3):386-391

22. Poersch NL, Ribeiro ND, Rosae DP, Possobom MTDF (2011) Genetic control of potassium content of common bean seeds. Pesquisa Aro Brasil 46(6):626-632

23. Raigon MD, Prohens J, Munoz-Falcon JE, Nuez F (2008) Comparison of eggplant landraces and commercial varieties for fruit content of phenolics, minerals, dry matter and protein. J Food Compos Anal 21:370-376

24. Ramakrishnan S, Enghlid JJ, Bryant HL, Xu FJ (1989) Characterization of a translation inhibitory protein from Luffa aegyptiaca. Biochem Biophys Res Commun 160(2):509-516
25. Ranganna S (2001) Handbook of analysis and quality control for fruit and vegetable products, 2nd edn. Tata McGraw-Hill, New Delhi

26. Rao BN, Rao PV, Reddy YN (2000) Combining ability studies in ridge gourd [Luffa actuangula (Roxb.) L.]. Int J Trop Agric 18(2):141-146

27. Re R, Pellegrini N, Proteggente A, Pannala A, Yang M, RiceEvans C (1999) Antioxidant activity applying an improved ABTS radical cation decolorization assay. Free Radic Biol Med 26:1231-1237

28. Simon PW (1992) Genetic improvement of vegetable carotene content. In: Bills DD, Kung SD (eds) Biotechnology and nutrition. Proc 3rd Int Symp, Butterworth-Heinemann, London, UK, pp. 291-300

29. Singh BK (2007) Studies on variability and heterosis of important economic and nutritive traits in cabbage (Brassica oleracea var. capitata L). Ph.D. thesis, Division of Vegetable Science, IARI, New Delhi, India

30. Singh D, Chhonkar PK, Pandey RN (1999) Soil plant water analysis: a methods manual. Division of Soil Science, IARI, Pusa, New Delhi

31. Singh BK, Sharma SR, Singh B (2009) Heterosis for mineral elements in single cross hybrids of cabbage (Brassica oleracea var. capitata L.). Sci Hortic 122:32-36

32. Singh BK, Sharma SR, Singh B (2012) Genetic combining ability for concentration of mineral elements in cabbage head (Brassica oleracea var. capitata L.). Euphytica 184:265-273

33. Singleton VL, Orthofer R, Lamuela-Raventos RM (1999) Analysis of total phenols and other oxidation substrates and antioxidant by means of Folin-Ciocalteu reagent. Methods Enzymol 299:152-178

34. Sit AK, Sirohi PS (2000) Gene action of nutritional traits of bottle gourd (Lagenaria siceraria Mol. Standl). Veg Sci 27(1):25-27

35. Tommonaro G, Prisco R, Abbamondi GR, Marzocco S, Saturnino C, Poli A, Nicolaus B (2012) Evaluation of antioxidant properties, total phenolic content, and biological activities of new tomato hybrids of industrial interest. J Med Food 15(5):483-489

36. Xu S, Hu J, Tan H, Zhang S (2008) Effects of genotype and environment on vitamin $\mathrm{C}$ content and its heterosis in towel gourd fruits. J Sci Food Agric 88:290-293 